\title{
Stable inheritance of shuttle vectors based on plasmid pIM13 in a mutant strain of Clostridium acetobutylicum
}

\author{
Houssine Azeddoug, JaCQues Hubert and Gilles ReysSeT* \\ Unité des Anaérobies, Institut Pasteur, 25 rue du Docteur Roux, 75724 Paris Cédex 15, France
}

(Received 3 February 1992; revised 5 April 1992; accepted 13 April 1992)

\begin{abstract}
New shuttle vectors for Clostridium acetobutylicum were constructed, using as replicons the Gram-positive plasmid pIM13, and derivatives of the Gram-negative plasmid pBR322, including pUC19. These vectors transformed $C$. acetobutylicum at a high frequency (up to $10^{6}$ transformants per $\mu \mathrm{g}$ DNA) by PEG-mediated protoplast transformation. A mutant host strain, NI-4082, was isolated on the basis of its ability to maintain plasmid pIM13 stably in the absence of selection pressure. The shuttle vectors showed no segregational or structural instability in this mutant strain. Moreover, the results suggested a relationship between segregational instability and the multimerization of pIM13 in C. acetobutylicum. The host/vector system described possessed all the properties required for efficient gene cloning in this species.
\end{abstract}

\section{Introduction}

Considerable work has been carried out in recent years towards the development of genetic tools for the butanolacetone clostridia. The first, recently achieved, step was the development of efficient gene transfer procedures. These were performed either by conjugation (Oultram $e t$ al., 1987, 1988a), or by electrotransformation (Oultram et al., 1988b) of vegetative cells and, in the case of Clostridium acetobutylicum strain NI-4081, by PEGmediated transformation of protoplasts (Reysset et al., 1988). Cloning and shuttle vectors have been constructed using either indigenous clostridial plasmids or heterologous replicons, originating largely from streptococci or bacilli. Unfortunately, irrespective of the plasmid/host systems used, the constructed replicons tended to show segregational instability (for details see the review of Young et al., 1989). The instability of plasmids bearing the replication functions of pIM13, originally from Bacillus subtilis (Mahler \& Halvorson, 1980), has now been resolved by selecting a mutant strain of $C$. acetobutylicum denoted NI-4082. In this strain, plasmid pIM13 was stably maintained in the absence of selection pressure. This allowed the construction of shuttle vectors capable of replicating in this organism, in Escherichia coli and in $B$. subtilis.

* Author for correspondence. Tel. (1) 45688311 ; fax (1) 43069835.

\section{Methods}

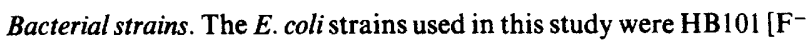
hsdS20 $\left(\mathrm{r}_{\overline{\mathrm{B}}}^{-} \mathrm{m}_{\overline{\mathrm{B}}}^{-}\right)$recA13 ara-14 lacY1 proA2 galK2 rpsL20 $\left(\mathrm{Sm}^{\mathrm{r}}\right)$ xyl-5 $m t l-1$ supE44 $\left(\lambda^{-}\right)$] (Boyer \& Roulland-Dussoix, 1969) and GT869

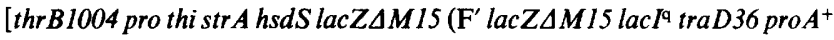
proB $\left.B^{+}\right)$] (Parsot, 1986). C. acetobutylicum strain NI-4081 (Rif ${ }^{-}$Pro $^{-}$ Lyt $^{-}$) (Reysset et al., 1987) was a derivative of strain NI-4 (Hongo, 1960). Strain NI-4082 was selected from NI-4081 for its ability to maintain pIM13 stably (this report). B. subtilis strain BD224 (recE4 thr$5 \operatorname{trpC2}$ ) was used as recipient for plasmid transformation (Dubnau et al., 1973).

Plasmids. The $E$. coli plasmid pBR322 was constructed by Bolivar $e t$ al. (1977) and pUC19 by Yanisch-Perron et al. (1985). The B. subtilis plasmid pIM13 (Mahler \& Halvorson, 1980), and Staphylococcus aureus plasmids pT127 (Novick \& Brodsky, 1972) and pBC16 1 l (Polak \& Novick, 1982), were also used. The $C$. acetobutylicum cloning vector pKNT14 has been described previously (Truffaut et al., 1989). The shuttle vector pCTC511 (Williams et al., 1990) was also used as a control. pKNT15 and pKNT19 are new E. coli/B. subtilis/C. acetobutylicum shuttle vectors (this report).

Media and growth conditions. E. coli strains were grown aerobically at $37^{\circ} \mathrm{C}$ in LB medium (containing, per litre : tryptone, $10 \mathrm{~g}$; yeast extract, $5 \mathrm{~g} ; \mathrm{NaCl}, 10 \mathrm{~g}$ ) or in LB medium solidified with $1.5 \%(\mathrm{w} / \mathrm{v})$ agar (Difco). Ampicillin (Ap) or erythromycin (Em), were added to the media when required to a final concentration of 100 and $300 \mu \mathrm{g} \mathrm{ml}^{-1}$, respectively. For $\beta$-galactosidase assay on plates, the chromogenic substrate 5-bromo-4-chloro-3-indolyl $\beta$-D-galactopyranoside (X-Gal) and the lac $Z$ inducer isopropyl $\beta$-D-thiogalactopyranoside (IPTG) (Boehringer Mannheim) were added to LB medium at final concentrations of 50 and $150 \mu \mathrm{g} \mathrm{ml}^{-1}$, respectively.

B. subtilis strains were grown at $37^{\circ} \mathrm{C}$ in Difco nutrient broth 
(Schaeffer et al., 1965); erythromycin was added to the medium when required to a final concentration of $5 \mu \mathrm{g} \mathrm{ml}^{-1}$.

For C. acetobutylicum, TYA medium (Ogata \& Hongo, 1973) was used for routine growth and plasmid segregation studies. T70 medium, derived from the previously described T69 medium (Reysset $e t$ al., 1987), was also used; it contained, per litre: $\mathrm{KH}_{2} \mathrm{PO}_{4}, 0.5 \mathrm{~g}$; $\mathrm{CH}_{3} \mathrm{COONH}_{4}, 3 \mathrm{~g} ; \mathrm{MgSO}_{4} .7 \mathrm{H}_{2} \mathrm{O}, 0.3 \mathrm{~g} ; \mathrm{MOPS}, 10 \mathrm{~g} ; \mathrm{NaHCO}_{3}$, $0.5 \mathrm{~g}$; biogelytone (bio-Mérieux), $1 \mathrm{~g}$; Casamino acids (Difco), $1 \mathrm{~g}$. Both media were adjusted to $\mathrm{pH} 6.5$ with $\mathrm{NaOH}$. Glucose and $\mathrm{CaCl}_{2}$ were added aseptically to a final concentration of $1 \%(w / v)$ and $1 \mathrm{mM}$, respectively. For plating, media were solidified with agar (Difco) at $1.8 \%(\mathrm{w} / \mathrm{v})$. Erythromycin or tetracycline $(\mathrm{Tc})$ were added to media when required to a final concentration of 50 and $8 \mu \mathrm{g} \mathrm{ml}^{-1}$, respectively.

Media derived from T70 were used for protoplast formation and regeneration (see below).

Media and supplements were pre-reduced and anaerobically sterilized, except for lysozyme, BSA and choline solutions, which were sterilized by filtration $(0.45 \mu \mathrm{m}$ pore size; Millipore).

All manipulations with $C$. acetobutylicum were carried out in an anaerobic chamber (Celser $\mathrm{La}$ Calhene) with an atmosphere of $\mathrm{N}_{2} / \mathrm{CO}_{2} / \mathrm{H}_{2}(90: 5: 5$, by vol.). Cultures were incubated in this chamber at 35 or $25^{\circ} \mathrm{C}$ when specified.

Protoplast formation and regeneration. Cells were grown in $\mathrm{T} 70$ medium to mid-exponential phase (about $1 \times 10^{8}$ cells ml-1). Cultures were adjusted with pre-weighed solid sterilized sucrose to $0.6 \mathrm{M}$. Protoplasts were obtained by adding lysozyme $\left(100 \mu \mathrm{g} \mathrm{ml}^{-1}\right)$ plus benzylpenicillin $\left(20 \mu \mathrm{g} \mathrm{ml}^{-1}\right)$, and incubating at $35^{\circ} \mathrm{C}$ for $60 \mathrm{~min}$. After addition of BSA, $0.5 \%$ final concentration, the protoplasts were recovered by centrifugation ( $4 \mathrm{~min}$ at 13000 r.p.m., MSE-micro Centaur) at room temperature, washed twice with T70 medium containing $0.5 \mathrm{M}$-xylose, $0.5 \% \mathrm{BSA}(\mathrm{T} 70-2 \mathrm{X})$, and resuspended in T70-2X. The protoplasts were then diluted and incorporated into soft agar regeneration medium (T70-X), i.e. T70 basal medium containing $0.25 \mathrm{M}$-xylose (pre-weighed solid sterilized), $0.5 \% \mathrm{BSA}$ and $0.4 \%(\mathrm{w} / \mathrm{v})$ choline, plus $0.8 \%(\mathrm{w} / \mathrm{v})$ agar (Difco), and spread onto the same medium solidified with $2.5 \%$ (w/v) agar (Difco).

Plasmid stability. Exponential-phase cultures $\left(\mathrm{OD}_{550}=0.3\right)$ of $C$. acetobutylicum were diluted and grown in TYA medium under nonselective conditions at $25^{\circ} \mathrm{C}$ or $35^{\circ} \mathrm{C}$ so that the original $\mathrm{OD}_{550}$ was recovered after about 20 generations. The dilutions were repeated to obtain about 40,60 and 80 generations. The percentage of clones maintaining resistance to erythromycin was determined by the replicaplating method. At every dilution step (about 20-40-60-80 generations) 24 erythromycin-resistant clones were checked for the presence of plasmid.

Plasmid transformation procedure. E. coli HB101 and GT869 were transformed by electroporation (Dower et al., 1988). Competent cells of B. subtilis were prepared according to the method of Anagnostopoulos \& Spizizen (1961). Protoplast transformation of $C$. acetobutylicum strains NI-4081 and NI-4082 was performed as follows. Plasmid DNA $(0 \cdot 1$ to $1 \mu \mathrm{g})$ was added to about $2 \times 10^{8}$ to $1 \times 10^{9}$ protoplasts prepared as described above. A solution of $40 \%(w / v)$ PEG 4000 prepared in T70 containing $0.5 \mathrm{M}$-xylose and $20 \mathrm{mM}-\mathrm{MgCl}_{2}$ was filter-sterilized, and then added at a final concentration of $35 \%$ to the protoplast suspension. This was gently mixed and incubated for $2 \mathrm{~min}$ at room temperature, then diluted with about 5 vols T70-2X medium, centrifuged (6 min at 13000 r.p.m), washed with the same medium and resuspended after centrifugation (4 min at 13000 r.p.m.) in T70-X medium. Appropriate dilutions of $C$. acetobutylicum protoplasts were incorporated into soft agar and poured onto regeneration plates (see above). After $20 \mathrm{~h}, 3 \mathrm{ml}$ of T70-X soft agar containing erythromycin $(1 \mathrm{mg})$ or tetracycline $(160 \mu \mathrm{g})$ was poured onto the plates. $\mathrm{Em}^{\mathrm{r}}$ or $\mathrm{Tc}^{\mathrm{r}}$ transformants appeared after 4 to $6 \mathrm{~d}$ incubation.
Plasmid isolation. The procedure of Birnboim \& Doly (1979) was used for small- and large-scale isolation of plasmid DNA from $E$. coli cells. Similar methods were developed for $C$. acetobutylicum (Reysset et al., 1988 ) and were also used for $B$. subtilis.

DNA manipulation. Restriction endonuclease and $\mathrm{T}_{4}$ DNA ligase were obtained from Boehringer Mannheim, Appligene, Gibco-BRL or Pharmacia. Digestion and ligation were carried out using the buffers and the concentrations suggested by the manufacturers.

Agarose gel electrophoresis was performed with horizontal $9 \times 11 \mathrm{~cm}$ slab gels in either TBE ( $90 \mathrm{~mm}$-Tris/borate, $2 \mathrm{mM}$-EDTA) or TAE ( $40 \mathrm{~mm}$-Tris, $5 \mathrm{~mm}$-sodium acetate, $1 \mathrm{~mm}$-EDTA adjusted to pH 7.8 with glacial acetic acid) buffers. Agarose concentrations of 0.7 and $1 \%(\mathrm{w} / \mathrm{v})$ were used, depending on the fragment sizes to be resolved. After electrophoresis, the gels were stained in ethidium bromide $\left(1 \mu \mathrm{g} \mathrm{ml}^{-1}\right)$ for $10 \mathrm{~min}$ and the DNA bands were visualized under a UV-light transilluminator ( $302 \mathrm{~nm}$; UVP, Inc.). Fragment sizes were determined by the method of Southern (1979) using phage $\lambda$ DNA digested with HindIII or HindIII and EcoRI as size standards (Daniels et al., 1980).

The isolation and detection of single-stranded (ss) plasmid DNA in whole-cell lysates were as described by te Riele et al. (1986).

Plasmid curing. The elimination of plasmids in regenerating protoplasts was first observed by Novick et al. (1980) for Staphylococcus aureus. Protoplasts of $C$. acetobutylicum strain NI-4082(pIM13) were prepared as previously described, except that the liquid and solid regeneration medium was devoid of choline and that $0.25 \mathrm{M}$-xylose was substituted by $0.3 \mathrm{M}$-sucrose. After regeneration, the colonies were replicated on plates with or without erythromycin $\left(50 \mu \mathrm{g} \mathrm{ml}^{-1}\right)$. About $3 \%$ of the regenerated protoplasts were found to be $\mathrm{Em}^{\mathrm{s}}$. These clones were checked for the absence of plasmid using the miniscale preparation.

\section{Results}

\section{Construction and properties of shuttle vectors}

The shuttle vector pKNT15 is a chimaeric plasmid consisting of pKNT14 and a derivative of pBR322, pBR322 $\Delta$, lacking a $1.9 \mathrm{~kb} E c o \mathrm{RV}-P v u \mathrm{II}$ fragment. pBR322 $\triangle$ was digested with HindIII and ligated to pKNT14 partially digested with the same restriction enzyme. The mixture was used to transform $E$. coli HB101 and recombinants were selected for both ampicillin and erythromycin resistance. Among the four types of recombinant plasmids of the expected size $(6.8 \mathrm{~kb})$, one, pKNT15, was retained for further studies. The construction and restriction map of this plasmid are shown in Fig. 1.

To construct pKNT19, plasmids pIM13 and pUC19 were linearized with ClaI and NarI, respectively. The fragments were ligated and used to transform $E$. coli GT869. Transformants were selected for erythromycin resistance and screened for $\beta$-galactosidase activity. The construction of one hybrid plasmid recovered, named pKNT19 $(4.9 \mathrm{~kb})$, is shown in Fig. 1.

The plasmids pKNT15 and pKNT19 prepared in dam $^{+}$strains of E. coli (Azeddoug et al., 1989) transformed $C$. acetobutylicum strain NI-4081 with high 


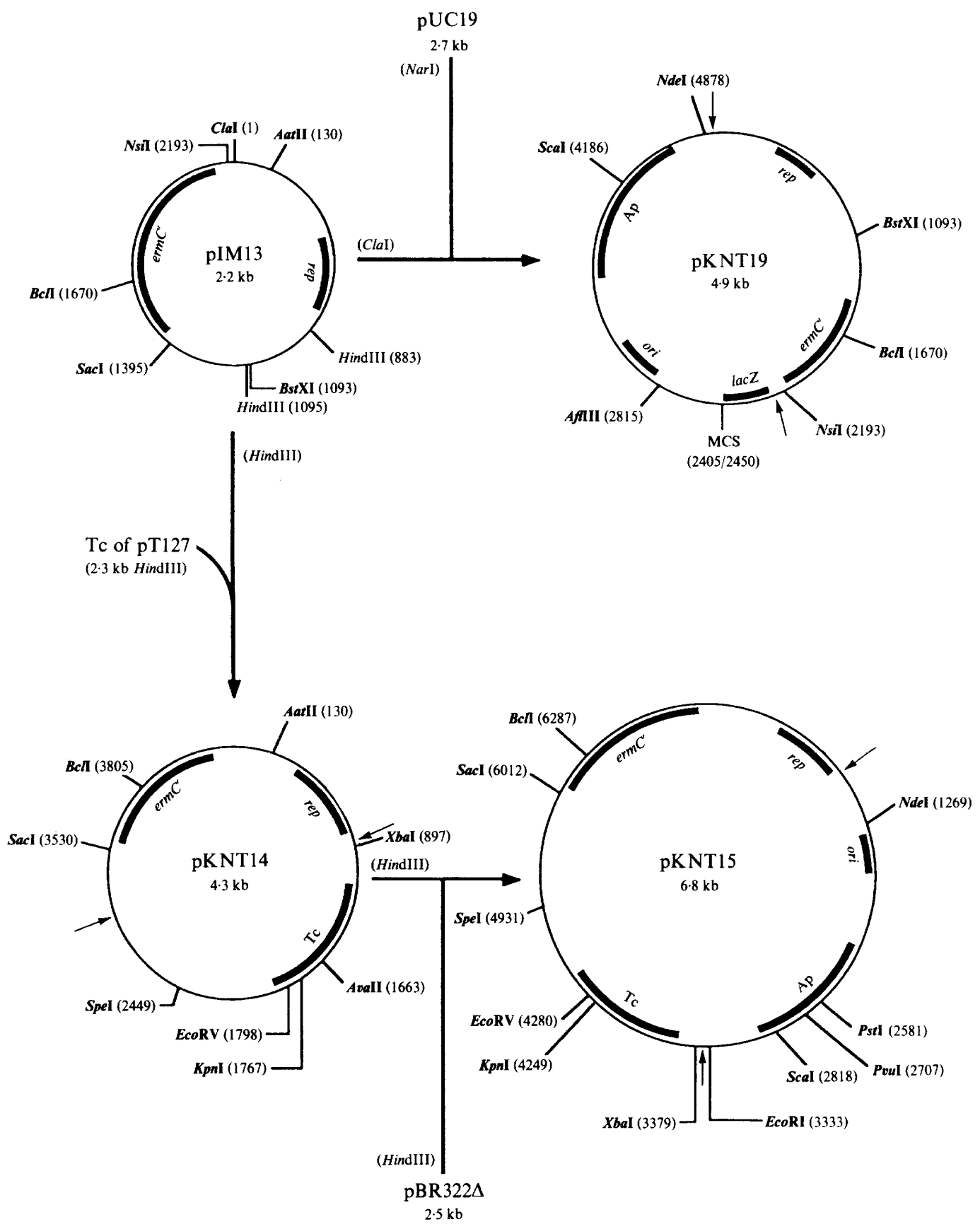

Fig. 1. Construction of hybrid plasmids pKNT15 and pKNT19. Plasmid pKNT15 was obtained by ligation of a partial HindIII digest of pKNT14 and a total HindIII digest of pBR322 (pBR322 deleted of the $1.9 \mathrm{~kb}$ EcoRV-PvuII fragment). Plasmid pIM13, digested by ClaI, was ligated to NarI-digested pUC19 to generate pKNT19. The main unique restriction sites available for cloning are shown in bold type. Nucleotide numbering starts for all plasmids at the first A of the ClaI site of pIM13 (Monod et al., 1986). The arrows represent the junction sites used in the construction of the hybrid plasmids. The AccI, HincII, HindIII and SacI sites of the multiple cloning sequence (MCS) of pUC19 were also present in pIM13.

efficiency, ranging from $2 \times 10^{6}$ to $6 \times 10^{6}$ transformants per $\mu \mathrm{g}$ of DNA, using the PEG-mediated protoplast procedure. The phenotypic properties of the two vectors either in $E$. coli or $C$. acetobutylicum are summarized in Table 1, and insertional cloning sites are given in Fig. 1.

\section{Isolation of strain NI-4082}

A high degree of structural and segregational stability is essential for efficient host/vector cloning systems. Although the recombinant plasmids showed good structural stability in C. acetobutylicum strain NI-4081, they 
Table 1. General properties of plasmid pIM13 and derivatives

\begin{tabular}{|c|c|c|c|c|c|}
\hline \multirow[b]{2}{*}{ Plasmid } & \multirow{2}{*}{$\begin{array}{l}\text { Size } \\
(\mathrm{kb})\end{array}$} & \multicolumn{2}{|c|}{ Replicon } & \multicolumn{2}{|c|}{ Phenotypic traits expressed in } \\
\hline & & Gram + ve & Gram - ve & Gram + ve & Gram - ve \\
\hline plM13 & $2 \cdot 2$ & pIMI3 & - & $\mathrm{Em}^{\mathrm{r}}$ & - \\
\hline pKNT14 & $4 \cdot 3$ & pIM13 & - & $E m^{r} T_{c}^{r}$ & $\ldots$ \\
\hline pKNT15 & 6.8 & pIM13 & pBR322 $\Delta^{*}$ & $\operatorname{Em}^{r} T^{r}{ }^{r}$ & $E m^{r} \dagger A p^{r}$ \\
\hline pKNT19 & 4.9 & pIM13 & pUC19 & $\mathrm{Em}^{\mathrm{r}}$ & $\mathrm{Em}^{\mathrm{r}}+\mathrm{Ap}^{r} \mathrm{Lac}^{+}$ \\
\hline
\end{tabular}

* The deletion $(\Delta)$ of $1.9 \mathrm{~kb}$ was generated between the $E c o \mathrm{RV}$ and $P v u \mathrm{II}$ sites of pBR322.

† Selection for erythromycin resistance in $E$. coli was feasible, but the efficiency of transformation was half that for ampicillin resistance and clones appeared $8 \mathrm{~h}$ later.

exhibited poor segregational stability. As the Grampositive replicon of a range of shuttle vectors, the segregational stability of pIM13 was evaluated in strain NI-4081. The results given in Fig. 2 clearly demonstrate the high segregational instability of pIM13. Moreover the instability was higher at $25^{\circ} \mathrm{C}$ than at $35^{\circ} \mathrm{C}$.

As shown in Fig. 2, after 43 generations only $0.1 \%$ of the NI-4081 cells remained $\mathrm{Em}^{\mathrm{r}}$. However, when transfers without antibiotic were continued, this percentage was maintained, even after 90 generations. At this step the cells were grown in TYA medium containing $50 \mu \mathrm{g}$ erythromycin $\mathrm{ml}^{-1}$ and then transferred at midexponential phase into TYA lacking the antibiotic. After three successive subcultures into TYA plus erythromycin followed by TYA without erythromycin, all 2500 clones tested by replica plating exhibited erythromycin resistance. All 24 clones chosen at random and checked for

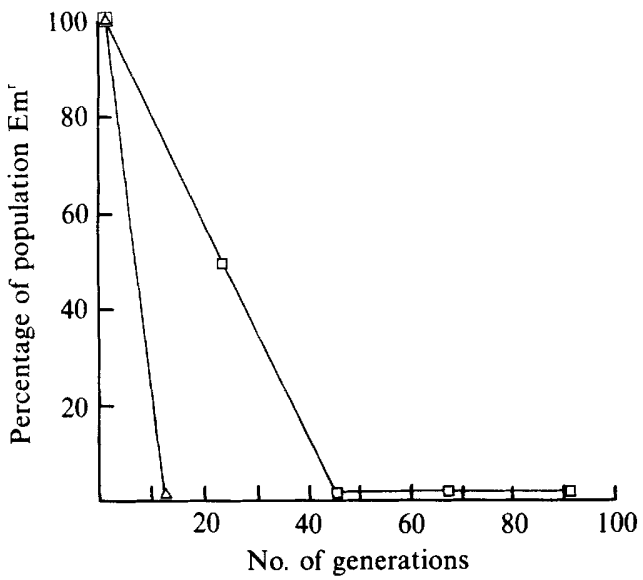

Fig. 2. Segregational stability of plasmid pIM13 in C. acetobutylicum strain NI-4081 at 25 and $35^{\circ} \mathrm{C}$. C. acetobutylicum strain NI-4081 harbouring plasmid pIM13 was grown in antibiotic-free TYA medium for approximately 90 generations at $25^{\circ} \mathrm{C}(\triangle)$ or $35^{\circ} \mathrm{C}(\square)$. The proportion of $\mathrm{Em}^{\mathrm{r}}$ cells was determined by replica-plating from nonselective media onto erythromycin-containing plates. At least 200 colonies were tested for each sample. the presence of plasmid DNA possessed the entire pIM13 replicon. One clone, NI-4082, was cured of the resident plasmid by the regeneration procedure (Novick et al., 1980).

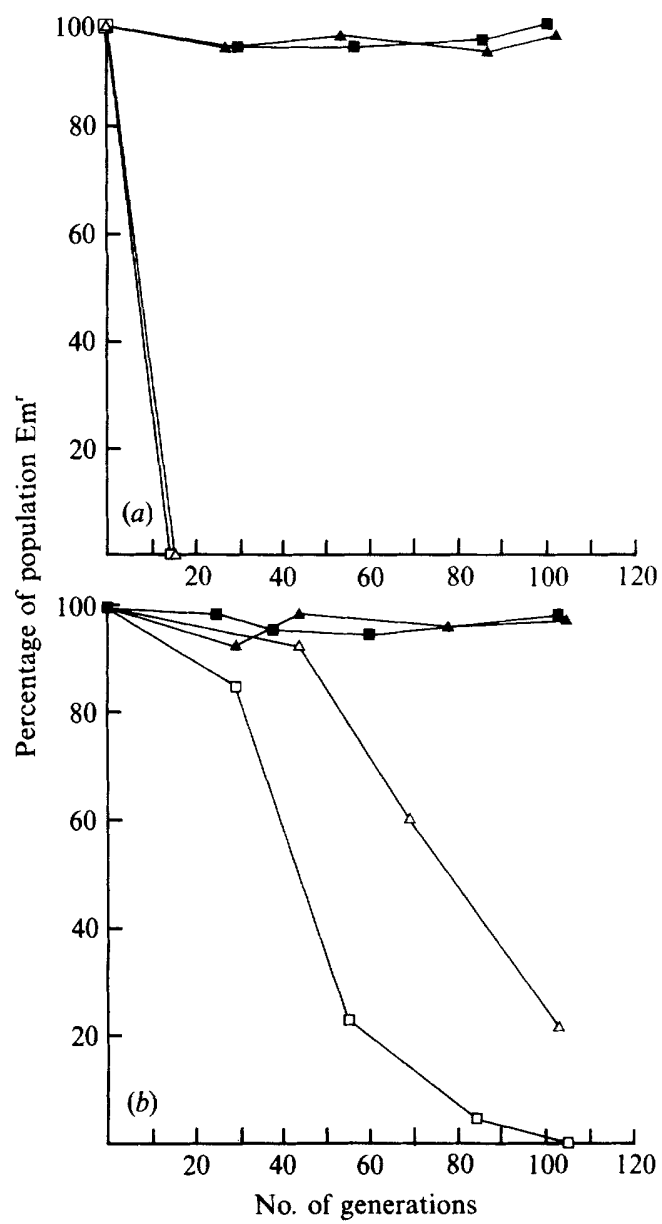

Fig. 3. Segregational stability of cloning vectors in $C$. acetobutylicum strain NI-4081 and NI-4082 at 25 and $35^{\circ} \mathrm{C}$. C. acetobutylicum strains NI-4081 and NI-4082 harbouring plasmid pK NT15 or pKNT19 were tested for segregational stability at $(a) 25^{\circ} \mathrm{C}$ and $(b) 35^{\circ} \mathrm{C}$ as described in the legend to Fig. 2. ( $\square$ ), NI-4081(pKNT15); $\triangle$ ), NI-4081 (pKNT19); $\square$, NI-4082(pKNT15); $\Delta$, NI-4082(pKNT19). 


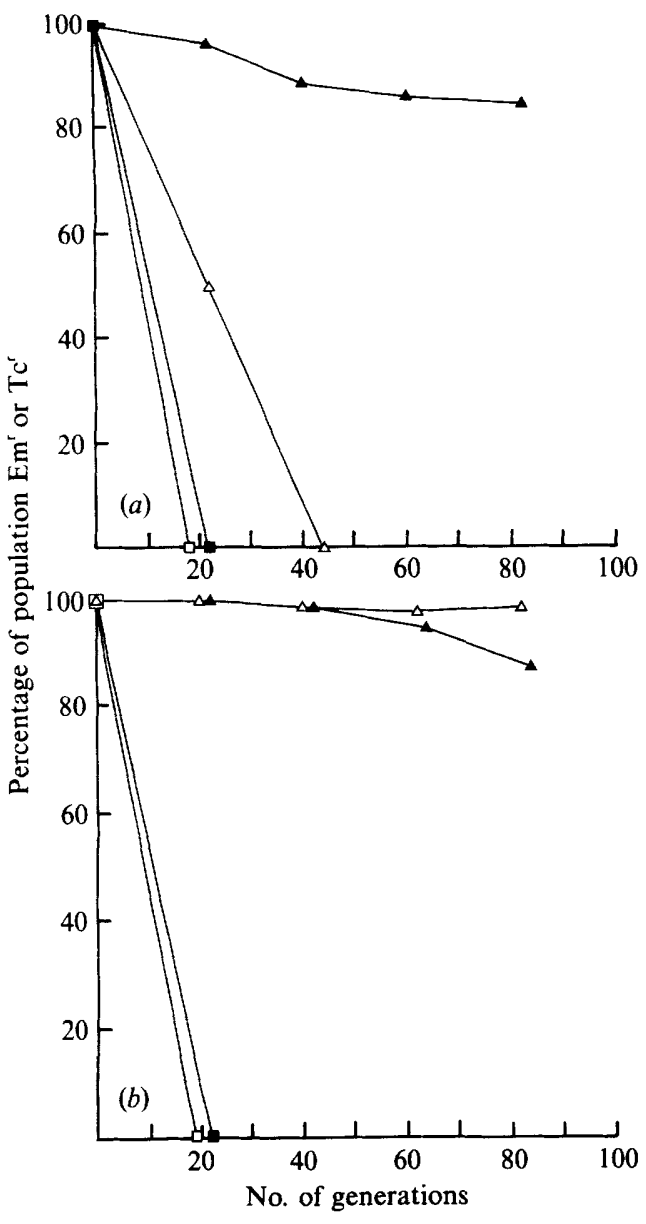

Fig. 4. Segregational stability of different replicons in C. acetobutylicum strains NI-4081 and NI-4082 at $35^{\circ} \mathrm{C}$. C. acetobutylicum strains NI-4081 $(a)$ and NI-4082 (b) harbouring plasmid pBC16 $\Delta 1(\square)$, pT127 (a), pIM13 $(\triangle)$ or pCTC511 ( $)$ were tested for segregational stability at $35^{\circ} \mathrm{C}$ as described in the legend to Fig. 2. The proportion of $\mathrm{Em}^{\mathrm{r}}$ or $\mathrm{Tc}^{\mathrm{r}}$ cells was determined by replica-plating from non-selective media onto antibiotic-containing plates.

Studies on the segregational stability of the two strains of C. acetobutylicum

The segregational stability of pIM13 derivatives was evaluated in strains NI-4081 and NI-4082 at $25^{\circ} \mathrm{C}$ (Fig. $3 a$ ) and $35^{\circ} \mathrm{C}$ (Fig. $3 b$ ). In strain NI-4081, the cloning vectors had the same instability as pIM 13 at $25^{\circ} \mathrm{C}$ but were slightly more stable at $35^{\circ} \mathrm{C}$. In contrast, no significant segregation was observed in strain NI-4082 cultivated at either temperature for 100 generations or more, whatever the vector tested. This suggested that the stability of the pIM13 replicon in strain NI-4082 was a property of the host strain rather than the plasmid during the selection procedure. It was also notable that stability of the pIM13 replicon in strain NI-4082 was independent of the temperature. Both strains harbouring pKNT19

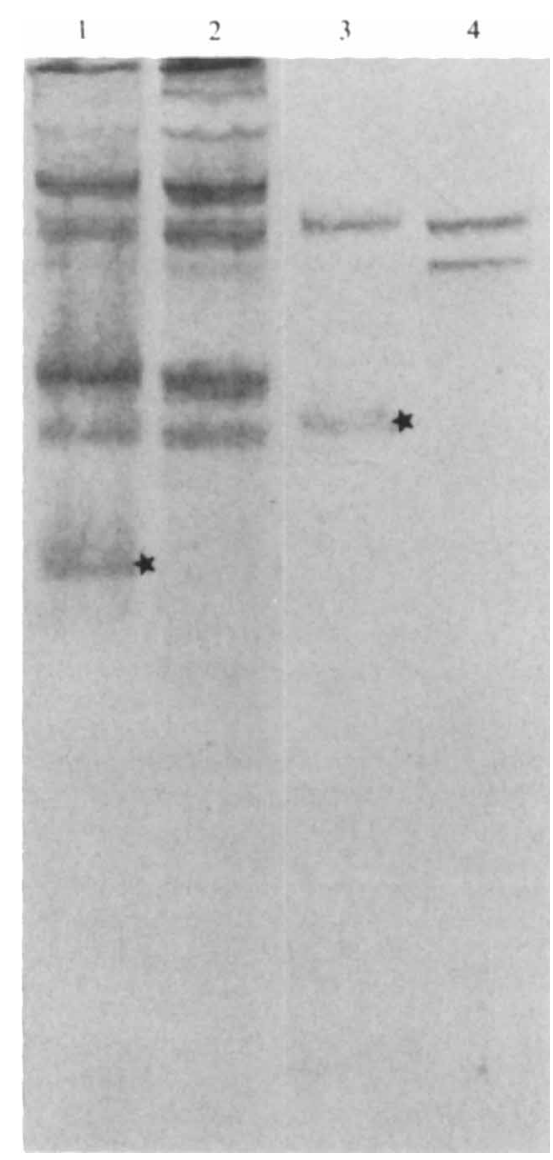

Fig. 5. Detection of single-stranded pKNT19 and pCTC511 DNA in strain NI-4081 of C. acetobutylicum. Cell lysates were prepared from $C$. acetobutylicum NI-4081 harbouring pKNT19 (lanes 1 and 2) or pCTC511 (lanes 3 and 4). Lysates were treated (lanes 2 and 4) or not treated (lanes 1 and 3 ) with nuclease S1, then electrophoresed through a $0.8 \%$ agarose gel. After transfer of DNA onto a nylon membrane, the filter was probed with ${ }^{35}$ S-labelled pKNT19. The single-stranded plasmid DNAs are indicated by stars.

were cultured in complex and semi-synthetic minimal media; no noticeable growth rate differences were observed between the two strains on either medium. But here also, the vector instability was observed in both media for strain NI-4081 only (data not shown).

Three other plasmids (pT127, pBC16 $1 \mathrm{l}$ and pCTC511) replicating like pIM13 in $B$. subtilis via rolling circle replication were introduced by transformation into both strains and tested for segregational stability at $35^{\circ} \mathrm{C}$. Results obtained in strains NI-4081 and NI-4082 are shown in Fig. $4(a)$ and $4(b)$ respectively. For plasmids pT127 and pBC16 161 only about $0.01 \%$ of the clones remained $\mathrm{Tc}^{\mathrm{r}}$ after 20 generations in the absence of selection pressure for either strain NI-4081 or NI4082. On the other hand, plasmid pCTC511 was rather stably maintained in both strains. 


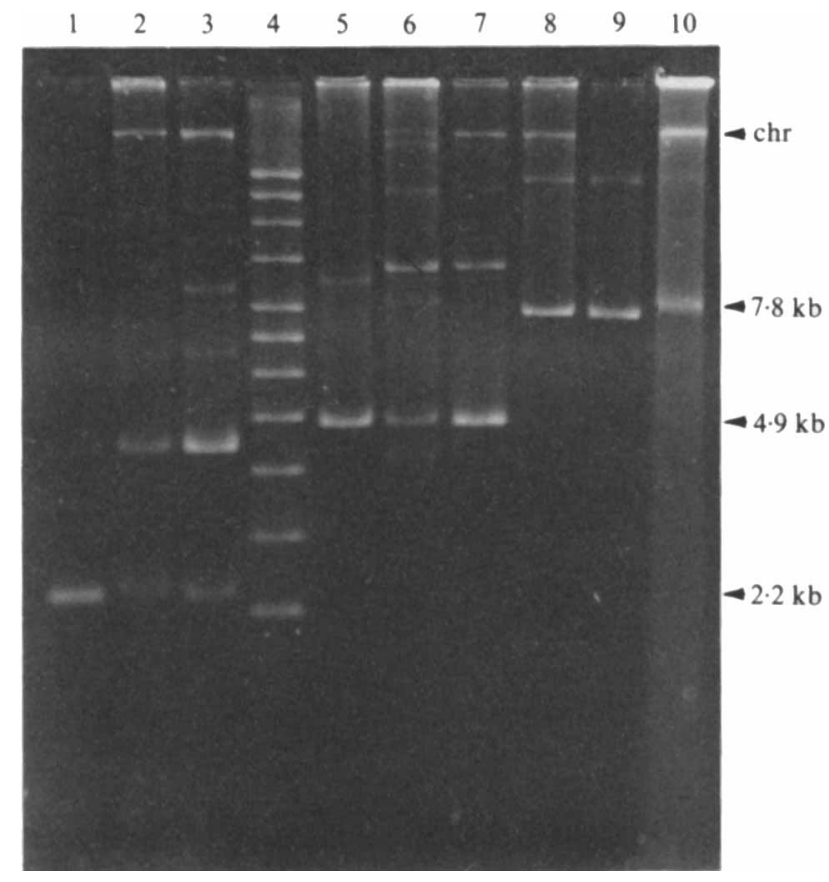

Fig. 6. Analysis of plasmid DNA preparations of pIM13, pKNT19 and pCTC511. Agarose gel $(0.8 \%)$ electrophoresis of small-scale preparations of pIM13, pKNT19 and pCTC511 plasmid DNA isolated from strains NI-4082 and NI-4081 of C. acetobutylicum and BD224 of B. subtilis. A ccc DNA ladder (bands of about 2, 3, 4, 5, 6, 7, 8, 10, 12, 14 and $16 \mathrm{~kb}$; Bethesda Research Laboratories) is shown in lane 4. Plasmid preparations are: pIM13 in strains NI-4082 (lane 1), NI-4081 (lane 2) and BD224 (lane 3); pKNT19 in strains NI-4082 (lane 5), NI4081 (lane 6) and BD224 (lane 7); pCTC511 in strains NI-4082 (lane 8), NI-4081 (lane 9) and BD224 (lane 10). The monomeric forms of plasmids pIM13 (2.2 kb), pKNT19 (4.9 kb) and pCTC511 (7.8 kb) are indicated by arrows. The upper band present on the gel corresponds to the chromosomal DNA (chr). Note that the band in front of the monomeric form of plasmid pKNT19 in strain NI-4081 was probably the relaxed form of the plasmid.

Vector pCTC511 was constructed using the Clostridium butyricum plasmid $\mathrm{pCB} 101$ rep region, consisting of two ORFs (B and C) essential for replication. As the ORF B polypeptide exhibited significant homology to the Rep proteins of staphylococcal plasmids pC194 and pUB1 10 and phage $\phi$ X174 (Minton et al., 1990a,b), it was suggested that $\mathrm{pCB} 101$ replicates via rolling circle replication, and belongs to the ssDNA family of Grampositive plasmids. It has been classified by Gruss \& Ehrlich (1989) in the pC194-type sub-group. Nevertheless, transformation of $B$. subtilis by pCTC511 strain BD224 occurred with poor efficiency as already observed by Collins et al. (1985) and Luczak et al. (1985), and plasmid DNA was barely detectable in isolates (see Fig. 6). In DNA preparations of plasmids pKNT19 and pCTC511 from strain NI-4081, ssDNA material sensitive to $\mathrm{S} 1$ nuclease activity was observed, demonstrating that pIM13 and pCB101 replicated via rolling circle replication in C. acetobutylicum (Fig. 5). Plasmid DNAs of pIM13, pKNT19 and pCTC511, prepared from an identical number of exponentially growing cells of strains NI-4081 and NI-4082, were electrophoresed on a $0.8 \%$ agarose gel, and compared with identical plasmids extracted from B. subtilis strain BD224 (Fig. 6). The same intensity of material stained with ethidium bromide was observed in the DNA preparations of the two $C$. acetobutylicum strains. This suggested that the stability of the pIM 13 replicon in strain NI-4082 was not related to a variation in plasmid copy number. Nevertheless, the banding patterns of the preparations were very different. Almost all DNA of plasmids pIM13 and pKNT19 from strain NI-4082 was present in the monomeric form, whereas in strain NI-4081 a significant amount of the plasmid DNA was present in multimeric forms (largely dimeric), as in B. subtilis (Monod et al., 1986). It was also observed that the same amount of plasmid pCTC511 was found, mostly in the monomeric form, in the two strains of $C$. acetobutylicum. For $B$. subtilis, only the monomeric form was detectable in highly concentrated preparations of pCTC511 (Fig. 6, lane 10).

\section{Discussion}

The small multicopy plasmids isolated from Grampositive aerobic bacteria (mainly from staphylococci and bacilli) have been divided into four groups (Novick, 1989) on the basis of similarity at the nucleotide sequence and functional organization levels. They replicate by an asymmetric rolling circle replication generating monomeric single-stranded circular DNA (ssDNA plasmids) (Gruss \& Ehrlich, 1989). These plasmids have been used extensively during the last decade to develop cloning vectors for Gram-positive eubacteria (Novick, 1989; Gruss \& Ehrlich, 1989), because they were shown to replicate in a wide variety of species. It was previously observed (Truffaut et al., 1989, and unpublished results) that amongst representative plasmids from the four groups (pT127; pC194 and pBC16 1; pIM13; pE194), only pIM1 3 replicated efficiently in strain NI-4081, but it was lost rapidly in the absence of a selective antibiotic. The E. coli-B. subtilis-C. acetobutylicum shuttle vectors pKNT15 and pKNT19 constructed with this replicon were similarly unstable in strain NI-4081. This difficulty has finally been overcome by the isolation of a mutant host strain, NI-4082, in which the vectors exhibited no detectable segregational instability. In contrast to experimental results reported for $B$. subtilis by Gruss \& Ehrlich (1988) and Bron et al. (1988, 1991), for cloning vectors based on ssDNA replicons, it was not possible, from gel electrophoretic analysis, to detect any structural instability. 
The mutation(s) selected during the enrichment procedure of strain NI-4082 appeared to be specific to pIM13 replication as two other ssDNA plasmids, pT127 and $\mathrm{pBC} 16 \Delta 1$, were still segregationally unstable in this new strain. In constrast, plasmid pCTC511, based on the clostridial pCB101 replicon, was easily established in $C$. acetobutylicum but not in B. subtilis (Collins et al., 1985; Luczak et al., 1985), and showed no segregational instability even in the parent strain NI-4081. This plasmid was shown to belong to the ssDNA family, but its replication strategy seems to be quite different from the Gram-positive plasmids of aerobic bacteria (Minton et al., 1990a, b).

We have clearly shown that the vectors based on pIM13 or pCB101 replicate in C. acetobutylicum strain NI-4081 and NI-4082 via rolling circle replication. A relationship between multimeric DNA formation and instability is suggested by the electrophoretic pattern of plasmid DNA prepared in both strains. In C. acetobutylicum, segregational stability should occur when most of the DNA is in the monomeric form. For vectors based on pIM13 replicon, this property was only shown in strain NI-4082; for plasmid pCTC511 this pattern was observed in both strains. A possible explanation for this observation is that resolution of multimeric forms of the pIM13-based plasmids is more efficient in strain NI-4082.

A similar association between multimerization and segregational instability for pIM13 and the closely related plasmid pE5 was also observed by Projan et al. (1987) in $S$. aureus but not in B. subtilis. These authors suggested that the multimerization was a property of the plasmid rather than of the strain. In contrast, the results presented here suggest that in $C$. acetobutylicum at least, the host functions may play an important role in plasmid stability.

The host genes involved in the stabilization of the pIM13 replicon have not yet been characterized, but they are of obvious interest. It will be necessary to understand why the genetic background of strain NI-4082 was inefficient for the replication of other ssDNA plasmids of aerobic Gram-positive bacteria. It should be noted here that plasmids of the pIM13 family are the only ssDNA plasmids in which the direction of replication is opposite to that of the direction of transcription of the rep gene (Novick, 1989). But even if valuable for one group only of ssDNA plasmids, a genetic modification of host strains may be of great value for improving plasmid stability.

We wish to thank M. Sebald for her support and advice throughout this work, F. Georges for her secretarial assistance and M. Goldner for critical reading of the manuscript.

This investigation was supported by research funds from the Institut Français de Pétrole.

\section{References}

Anagnostopoulos, C. \& Spizizen, J. (1961). Requirements for transformation in Bacillus subtilis. Journal of Bacteriology 81, 741746.

AzedDoug, H., Hubert, J. \& ReYsSet, G. (1989). Characterization of a methyl-specific restriction system in Clostridium acetobutylicum strain NI-4081. FEMS Microbiology Letters 65, 323-326.

Birnboim, H. C. \& Doly, J. (1979). A rapid alkaline extraction procedure for screening recombinant plasmid DNA. Nucleic Acids Research 7, 1513-1523.

Bolivar, F., Rodriguez, R. L., Greene, P. J., Betlach, M. C., Heynecker, H. L., Boyer, H. W., Crosa, J. H. \& Falkow, S. (1977). Construction and characterization of new cloning vehicles. II. A multipurpose cloning system. Gene 2, 95-113.

Boyer, H. W. \& Roulland-Dussoix, D. (1969). A complementation analysis of the restriction and modification of DNA in Escherichia coli. Journal of Molecular Biology 41, 459-472.

Bron, S., LuXen, E. \& SWART, P. (1988). Instability of recombinant pUB110 plasmids in Bacillus subtilis: plasmid-encoded stability function and effects of DNA inserts. Plasmid 19, 231-241.

Bron, S., Holsappel, S., Venema, G. \& Peeters, B. P. H. (1991). Plasmid deletion formation between short direct repeats in Bacillus subtilis is stimulated by single-stranded rolling-circle replication intermediates. Molecular and General Genetics 226, 88-96.

Collins, M. E., Oultram, J. D. \& Young, M. (1985). Identification of restriction fragments from two Clostridium butyricum plasmids that promote the establishment of a replication-defective plasmid in Bacillus subtilis. Journal of General Microbiology 131, 2097-2105.

DANiEls, D. L., DE WeT, J. R. \& BlattNeR, F. R. (1980). New map of bacteriophage lambda DNA. Journal of Virology 33, 390-400.

Dower, J. W., Miller, J. F. \& Ragsdale, C. W. (1988). High efficiency transformation of Escherichia coli by high voltage electroporation. Nucleic Acids Research 16, 6127-6145.

Dubnau, D., Davidoff-Abelson, R., Scher, B. \& Cirigliano, C. (1973). Fate of transforming deoxyribonucleic acid after uptake by competent Bacillus subtilis: phenotypic characterization of radiation-sensitive recombination-deficient mutants. Journal of Bacteriology 114, 273-286.

Gruss, A. \& EHRLICH, S. D. (1988). Insertion of foreign DNA into plasmid from gram-positive bacteria induces formation of highmolecular-weight plasmid multimers. Journal of Bacteriology 170, 1183-1190.

Gruss, A. \& EHRLICH, S. D. (1989). The family of highly interrelated single-stranded deoxyribonucleic acid plasmids. Microbiological Reviews 53, 231-241.

Hongo, M. (1960). US Patent no. 2945786.

Luczak, H., Schwarzmoser, H. \& Staudenbauer, W. L. (1985). Construction of Clostridium butyricum plasmids and transfer to Bacillus subtilis. Applied Microbiology and Biotechnology 23, 114-122.

MAHLER, I. \& HALVORSON, H. O. (1980). Two erythromycin resistance plasmids of diverse origin and their effect on sporulation in Bacillus subtilis. Journal of General Microbiology 120, 259-263.

Minton, N. P., Brehm, J. K., Oultram, J., Swinfield, T. J., Schimming, S., Whelan, S. E., Thompson, D. E., Young, M. \& StaudenbauER, W. L. (1990a). Development of genetic systems for Clostridium acetobutylicum. In Proceedings of the 6th International Symposium on Genetics of Industrial Microorganisms, pp. 759-770. Edited by H. Heslot, J. Davies, J. Florent, L. Bobichon, G. Durand \& L. Penasse. Paris: Société Française de Microbiologie.

Minton, N. P., Brehm, J. K., Oultram, J. D., Thompson, D. E., Swinfield, T.-J., Pennock, A., Schimming, S., Whelan, S. M., VetTer, U., Young, M. \& Staudenbauer, W. L. (1990 b). Vector systems for the genetic analysis of Clostridium acetobutylicum. In Clinical and Molecular Aspects of Anaerobes, pp. 187-201. Edited by S. P. Borriello. Petersfield: Wrightson Biomedical Publishing.

Monod, M., Denoya, C. \& Dubnau, D. (1986). Sequence and properties of pIM13, a macrolide-lincosamide-streptogramin B resistance plasmid from Bacillus subtilis. Journal of Bacteriology 167, 138-147.

Novick, R. P. (1989). Staphylococcal plasmids and their replication. Annual Review of Microbiology 43, 537-565. 
Novick, R. P. \& BRODSKY, R. (1972). Studies on plasmid replication. I. Plasmid incompatibility and establishment in Staphylococcus aureus. Journal of Molecular Biology 68, 285-302.

Novick, R., Sanchez-Rivas, C., Gruss, A. \& Edelman, I. (1980). Involvement of the cell envelope in plasmid maintenance: plasmid curing during the regeneration of protoplasts. Plasmid 3, 348-358.

OGATA, S. \& Hongo, M. (1973). Bacterial lysis of Clostridium species. I. Lysis of Clostridium species by univalent cation. Journal of General and Applied Microbiology 19, 251-261.

Oultram, J. D., Davies, A. \& Young, M. (1987). Conjugal transfer of a small plasmid from Bacillus subtilis to Clostridium acetobutylicum by cointegrate formation with plasmid pAM $\beta 1$. FEMS Microbiology Letters 42, 113-119.

Oultram, J. D., Peck, H., Brehm, J. K., Thompson, D. E., Swinfield, T. J. \& MinTon, N. P. (1988a). Introduction of genes for leucine biosynthesis from Clostridium pasteurianum into Clostridium acetobutylicum. Molecular and General Genetics 214, 177-179.

Oultram, J. D., Loughlin, M., Swinfield, T. J., Brehm, J. K., THOMPSON, D. E. \& MINTON, N. P. (1988b). Introduction of plasmids into whole cells of Clostridium acetobutylicum by electroporation. FEMS Microbiology Letters 56, 83-88.

PARSOT, C. (1986). Evolution of biosynthetic pathways: a common ancestor for threonine synthase, threonine dehydratase and D-serine dehydrase. EMBO Journal 5, 3013-3019.

PolaK, J. \& Novick, R. P. (1982). Closely related plasmids from Staphylococcus aureus and soil bacilli. Plasmid 7, 152-162.

Projan, S. J., Monod, M., Narayanan, C. S. \& Dubnau, D. (1987). Replication properties of pIM13, a naturally occurring plasmid found in Bacillus subtilis, and of its close relative $\mathrm{pE5}$, a plasmid native to Staphylococcus aureus. Journal of Bacteriology 169, 51315139.

te Riele, H., Michel, B. \& Ehrlich, S. D. (1986). Single-stranded plasmid DNA in Bacillus subtilis and Staphylococcus aureus. Proceedings of the National Academy of Sciences of the United States of America 83, 2541-2545.

Reysset, G., Hubert, J., Podvin, L. \& Sebald, M. (1987). Protoplast formation and regeneration of Clostridium acetobutylicum strain NI4080. Journal of General Microbiology 133, 2595-2600.

Reysset, G., Hubert, J., Podvin, L. \& Sebald, M. (1988). Transfection and transformation of Clostridium acetobutylicum strain NI-4081 protoplasts. Biotechnology Techniques 2, 199-204.

SChAeffer, P., Millet, J. \& AUberT, J.-P. (1965). Catabolic repression of bacterial sporulation. Proceedings of the National Academy of Sciences of the United States of America 54, 704-711.

Southern, E. M. (1979). Measurement of DNA length by gel electrophoresis. Analytical Biochemistry 100, 319-323.

Truffaut, N., Hubert, J. \& Reysset, G. (1989). Construction of shuttle vectors useful for transforming Clostridium acetobutylicum. FEMS Microbiology Letters 58, 15-20.

Williams, D. R., Young, D. I. \& Young, M. (1990). Conjugative plasmid transfer from Escherichia coli to Clostridium acetobutylicum. Journal of General Microbiology 136, 819-826.

YanisCh-Perron, C., Vieira, J. \& Messing, J. (1985). Improved M13 phage cloning vectors and host strains: nucleotide sequences of the M13mp18 and pUC19 vectors. Gene 33, 103-119.

Young, M., Minton, N. P. \& Staudenbauer, W. L. (1989). Recent advances in the genetics of the clostridia. FEMS Microbiology Reviews 63, 301-326. 